\title{
The Legal Policy of Executability in the International Arbitral Tribunal Decision
}

\author{
Rachel Georghea Sentani ${ }^{\mathrm{a}, 1, *}$, Mathijs ten Wolde ${ }^{\mathrm{a}, 2}$ \\ ${ }^{a}$ Faculty of Law, University of Groningen, Netherland \\ ${ }^{1}$ rgsentani@gmail.com *; ${ }^{2}$ m.h.ten.wolde@rug.nl \\ * corresponding author
}

ARTICLE INFO

Article history

Received: January 10, 2021

Revised: July 28, 2021

Accepted: August 29, 2021

Keywords

Legal Policy;

Executability;

Arbitral;

Investment;

\section{ABSTRACT}

The growing number of investment disputes indicates more challenging and controversial matters in the various arbitration practices. However, the International Centre for the Settlement of Investment Disputes (ICSID) rules do not entirely solve the problem in the arbitration process. This study aims to explain how the ICSID tribunal's inherent reconsideration power can be exercised to "fill the gap" in arbitration proceedings. This study concludes that it can be enforced under Article 44 of the ICSID Convention, which decides the question submitted to the tribunal that the ICSID Convention does not cover. Second, in completing this study, the wording of Rules 19 of Arbitration Rules gives an almost similar order to the tribunals in the case of absence in the conduct of proceedings. Third, under Rule 38 (2) Arbitration Rules, the tribunals can exercise the reconsideration power when discovering new facts that decisively affect the case's outcome.

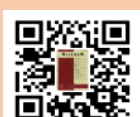

This is an open access article under the CC-BY 4.0 license.

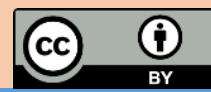

\section{Introduction}

The International Centre for the Settlement of Investment Disputes (ICSID) is an organization created by the Washington Convention (the ICSID Convention) to facilitate international investment by creating a body to settle disputes between investors and states that may arise from such investments. It aims to provide a forum for conflict resolution in a framework which carefully balances the interests and requirements of all the parties involved and attempt in particular to "depoliticize" the settlement of investment disputes (Thow et al., 2015). The development of ICSID is related to the particular jurisdiction to settle investments disputes covered by the international investment treaty. International element creates a consequence that disputes referred to ICSID must involve a State and a foreign investor.

A statistic data from ICSID based on cases registered or administered by ICSID as of December 31, 2016, illustrates that Bilateral Investment Treaty (BIT) is the highest basis of consent invoked to establish ICSID Jurisdiction in registered ICSID Case. Around 59.8\% of cases which enters the ICSID Arbitration is based on BIT then followed with Investment Contract between the Investor and the Host-State (16.7\%), Investment Law of the Host- State $(9.5 \%)$ and Energy Charter Treaty $(9.5 \%)$. The growing number of disputes under BIT consequently indicates more challenging and controversial matters in the various arbitration practices. This situation is understandable since litigants will typically use all procedural tools at their disposal in the high-stakes world of 
investment arbitration. One of the crucial issues is regarding the existence of the ICSID tribunals inherent power to reconsider its decision prior to the final award that has been found in the recent cases (Bhagwat et al., 2021).

The inherent power to reconsider the issue arises as a result of the absence of clear guidance on the topic, which risks leaving parties and arbitrators adrift when confronted with difficult situations for which the parties' agreement or the arbitral rules provide no roadmap. Besides, since reconsideration power is included as inherent powers that are basically controversial on its own, therefore the lengthy debates and various interpretations over tribunals' power to reconsider its former decision can be recognized (Thiel, 2018). Following this issue is the question that relates to arbitral tribunal's power to grant a request for revising or reconsidering its previous partial decisions when challenged with the finality and binding principle. Again, when the finality of the pre-award decision is still unsolved, where some judgments strictly held its finality to be the same as the finality of the final award, but others prefer to hold it as not final. The discussion about the finality character of tribunal's decision prior to award will also be provided in this thesis.

In general, ICSID Convention provides reconsideration as one of the explicit remedies that available for award in the practice of investment arbitration rendered under Article 48 of this Convention. However, as the development in the arbitration world continues, the party starts to demand the exercise of tribunal's reconsideration power issue on its decision prior to the final award. The different interpretation of this matter appears as the result of unclear guidelines that can be seen from the following judgments under several ICSID tribunals. It is important to bear in mind that there are three main cases which will be analyzed in this study: Conoco Phillips Petrozuata BV \& Ors v. Venezuela, Churchill Mining PLC and Planet Mining Pty Ltd v Republic of Indonesia and the Perenco Ecuador Limited v Republic of Ecuador (Chou et al., 2016).

In the judgments made by Conoco Phillips Petrozuata BV \& Ors v. Venezuela case, Tribunal (hereinafter Conoco Phillips Tribunal) and the Perenco Ecuador Limited v Republic of Ecuador case Tribunal (hereinafter Perenco Tribunal) decide to decline the reconsideration request made by the Parties as they are being asked to revise final award, for instance. These tribunals denied granting power for reconsideration as it is seen to be against the nature of arbitration award which is intended to be final and not to be revised by the Parties or the Tribunal in any later phase of their arbitration proceedings. The tribunals in both cases were favoring legal certainty and avoiding inefficient settlement. The majority of Conoco Phillips Tribunal, in denying the existence of reconsideration power, argued that interim decisions "as a matter of principle and practice" are intended to have res judicata effect and thus not subject to review separately from the final award. In his dissenting opinion, the remaining arbitrator Georges Abi-Saab gave strong critical against the majority's approach and analysis, saying that the Tribunal possesses an inherent power of reconsideration.

Following the majority decision of Conoco Phillips Tribunal, the Perenco Tribunal also denied the motion for reconsideration, concluding that none of the ICSID Convention's Articles or the ICSID Arbitration Rules vested it with a power 'to re-open, amend and/or reverse a decision preliminary to its award'. The tribunal ruled that once it had decided with finality any of the legal or factual questions presented to it, the decision became res judicata and could not be revised except in several circumstances provided in Article 51 of the ICSID Convention. On the other hand, the Churchill Mining PLC and Planet Mining Pty Ltd v Republic of Indonesia case Tribunal (hereinafter Churchill Tribunal), another ICSID tribunal, took different ways in dealing with a similar issue. The Churchill Tribunal issued Procedural Order No 15 in January 2015 which reaffirms a prior reconsideration in which it decided to bifurcate a liability issue. This tribunal confirmed that the power to reconsider an earlier decision is within ICSID tribunal's powers, setting aside the finality character of its prior decision (Nyarko, 2019).

This work will focus on providing a theoretical framework for the study of the elements that might constitute the inherent authority to reconsider tribunal's decision of ICSID tribunal with a view from situations that make the ICSID tribunal invoking such inherent powers if any, and the finality character of ICSID's decision prior to the final award. Further, it will examine the limitation of the Tribunal in exercising such power. In achieving this objective, the work will be divided into three parts: summarizes the factual background and the most relevant phases of the three ICSID tribunals' decision in determining whether it could grant a request for reconsideration of a partial 
decision with a view from each Tribunal's reasoning on its judgment (Junxia, 2019). The analysis is focused on the legal policy of executability in the international arbitral tribunal decision for settlement of investment disputes in the following cases: Conoco Phillips Petrozuata BV \& Ors v. Venezuela, Perenco Ecuador Limited v Republic of Ecuador and the Churchill Mining PLC and Planet Mining Pty Ltd v Republic of Indonesia and binding principle in ICSID Arbitration (Horn \& Tangerås, 2021).

\section{Results and Discussion}

\subsection{Finality and Binding Principle in the International Centre for the Settlement of Investment Disputes Arbitration}

There is only one award in an ICSID case. The Tribunal's last decision disposes of the case; however, the exact definition of an award that is internationally accepted and cannot be found anywhere in the international arbitration conventions. Although, ICSID Convention does not give a straightforward definition of the term "awards", Article 48 illustrates that an award is described as the final decision of an arbitral tribunal in written form and signed by the tribunal members who voted for it. An award also has to deal with every question submitted to the tribunal and state the reasoning upon which it is based. It has binding characteristics on the parties and shall not be subject to any appeal or any other remedy except those provided for (Oseni et al., 2016).

Moreover, Article 48 (3) specifically describes that an award is definitively final if the tribunal holds that it lacks jurisdiction or resolves all substantive issues on the merits. An award that affirms jurisdiction, and thus allows the case to proceed to the merits, is not a final award (and is denominated a decision). This description shows how the outcome of the tribunal can give finality and binding character under ICSID. Consequently, the ICSID Convention draws a clear distinction between an award and any interlocutory decisions reached earlier in the proceeding by the tribunal, so that provision regarding the review of an award does not apply to interlocutory decisions. Although the ICSID Convention is quite straightforward regarding the finality of the award rendered by the tribunal, it is in silence regarding the finality character of decisions outside the term 'award' (Rao, 2021).

Many consider the finality of awards to be one of the primary advantages of arbitration. Arbitral proceedings are even praised by their finality since under Article 52 (6) of the ICSID Convention, the only option available even when the ad hoc Committee already annulled the award is to resubmit the case for the arbitration de novo by a new tribunal. Finality is widely associated with arbitral decisions in general and refers to the lack of an appeals mechanism that allows the merits of the dispute to be reviewed. This aims to get effective dispute settlement and legal peace. However, according to Christoph H. Schreuer, the annulment mechanism allows the ICSID Convention to address a much broader conflict between those two principles affecting any process of review of a given judicial decision. The eventual finality of interlocutory decisions, which do not qualify as awards according to the ICSID Conventions, remains to be assessed (Chisik, 2012).

The tribunal's decision will be defined as 'award' only when it disposes of every question submitted to the tribunal based on Article 48 of the ICSID Convention. This article clearly shows the difference between awards and interlocutory decisions reached earlier by the tribunal. Article 54 attaches the principle of res judicata to awards only. Article 53 (1) provides that the award shall not be subject to any appeal or to any other remedy except those provided for in the Convention. However, the Convention provides several numbers of remedies and review procedures of the awards, such as revision, annulment, supplementation and interpretation. The system of review under the Convention is self-contained and does not permit any external review, including domestic courts. This principle also extends to the stage of recognition and enforcement of ICSID awards (Kohler \& Stähler, 2019).

ICSID Convention provides several grounds as a standard for the annulment of the awards that are listed exhaustively under Article 52 (1) either party may request annulment of the award by an application in writing addressed to the Secretary-General on one or more of the following grounds that the Tribunal was not properly constituted, that the Tribunal has manifestly exceeded its powers, that there was corruption on the part of the member of the Tribunal, that there has been serious 
departure from a fundamental rule of procedure and that the award has failed to state the reasons on which it is based (Gershoni, 2021). Two potentially conflicting principles are at work in the process of review of a judicial decision, the principle of finality and the principle of correctness. When the Tribunal is strict in applying the finality principle while the final decision was not made with full correctness, for instance: such an erroneous event happened in the procedural process, therefore, in justice is not served and the aim of the Tribunal is not well-achieved. This happens because the principle of fairness is not achieved. However, if the principle of correctness is demanded to be strict, which opens to be revisited in the later stage when an error of fact or law is found, hence it will affect the legal certainty of the awards.

The question relates to the finality of tribunal's decisions prior to award often arises due to a reconsideration request by the party in the arbitration proceedings. This leads to the never-ending controversy in many ICSID cases whether it is even possible to reconsider the tribunal's earlier decision since it is potentially against the final and binding principle. This is understandable as both ICSID Convention and ICSID Arbitration Rules are not specifically addressed whether the tribunal has the authority to do so. In practice the finality of pre-award varies based on tribunal's interpretation. The Tribunal in Electrabel SA v Republic of Hungary held that even though its decision is not described as "award" under the ICSID Convention, it is intended to be final and cannot be revisited either by the Parties or the Tribunal in any later phase of the proceedings. The same goes for the majority of Conoco Phillips Tribunal; as mentioned in the previous chapter of this study, it held that as a matter of principle and practice that such decisions that resolve points in dispute between the Parties have res judicata effect. In Perenco Ecuador Limited v. the Republic of Ecuador, although the tribunal strongly suggests that once the tribunal has established an issue, its decision generally becomes res judicata and cannot be revisited; it sets an additional requirement for this premises that 'unless [in] a very specific situation which calls out for the tribunal to revisit its prior findings is presented'. However, it held that there is no new fact which decisive to the case.

This strict view contends in Standard Chartered Bank (Hong Kong) Limited v Tanzania Electric Supply Company Limited (Tanesco) case. The Tanesco Tribunal acknowledged that holding all decisions of ICSID tribunals are res judicata can be too broad. In making decisions related to procedural matters and provisional measures, all are subjected to being reviewed, reconsidered, and revised, irrespective whether the Convention is silent on this matter. In the same vein, the tribunal in Churchill Mining PLC and the Planet Mining Pty Ltd v Republic of Indonesia, because both ICSID Convention and ICSID Arbitration Rules do not contain any prevention or prohibition for the tribunal to revisit, revise or reverse an earlier decision based on the reconsideration request to ensure the integrity of pre-award decision. This argument indirectly shows that decision is not deemed to be final and can be revisited at any time prior to award (Arthur, 2015).

Several important remarks can be noted from Abi-Saab's well-known dissenting opinion as for the arbitrator in Conoco Phillips Tribunal. From his perspective, decisions are not necessarily final or binding: By referring to Article 48, paragraph 3 of the ICSID Convention that "The award shall deal with every question submitted to the Tribunal...", therefore incomplete award cannot be considered final unless it incorporates all interlocutory decisions, these interlocutory decisions a fortiori cannot be considered final until they are thus incorporated as part of the whole. Regarding the request for reconsideration proceedings, according to Lisa M. Bohmer, it should only be accepted if it is already fulfilled the conditions for revision of an international decision developed by international practice, therefore a specific request for reconsideration has to be decided on a case-bycase basis. Moreover, Abi-Saab also urged that the interlocutory decision is not necessarily final or binding "particularly on the Tribunal itself if it becomes aware that it has committed an error". Consequently, if tribunal's decision prior to the final award is deemed to be not final when there are specific circumstances which affect the integrity of the award, then reconsideration can be the solution. However, if a tribunal is concerned about the finality and certainty of its decision, it leads to the absolute finality with only the opportunity to be revised from post-judgment remedies (Deffains et al., 2010).

In the end, it is visible that each side has a different concern in deciding the finality character of the pre-award decision. The tribunals' decision will be based on which principles which are more being favored of finality or correctness. One that supports extended finality in tribunal's decisions 
before rendering final award gives major concern to its decision's legal certainty and predictability. Meanwhile, another side who supports the view that decision is not necessary to be final in several limited circumstances aim to the correctness of final award in the later phase. However, it is very important to strike the balance of finality and correctness in seeking the truth justice.

\subsection{The Legal Policy of Executability in the International Arbitral Tribunal Decision for Settlement of Investment Disputes}

The adjective 'inherent' is used to describe something which 'exist[s] in something as a permanent attribute or quality a characteristic or essential element of something. The concept of inherent powers as a source of judicial power emerged first in England, where early judges, serving as the king's personal representatives, enjoyed substantial discretion in exercising the royal prerogative to do justice. They are used as a judicial basis for their judicial functions that are not expressly set out in the statute. This power is also being exercised in many other common law countries, including Australia, Canada, Singapore, and New Zealand, in addition to the United States and the United Kingdom. These courts have variously invoked inherent powers to make rules of court and practice directions, to prevent abuse of the court's process, to remand cases involving pendent claims, to stay proceedings, to correct any injustice caused by an earlier order, and to exercise control over persons before them.

Nowadays, it is a well-known fact that international tribunals also recognize the existence of inherent powers. However, the well-established practice does not seem to end the debate between legal scholars caused by the uncertainty of its source. Further, not every international judicial body had successfully explained why a particular power was characterized as 'inherent' even though the exercise of such power could be expected from their constitutive instruments, although some find a way to point out. This means that the source of inherent power might be from anywhere if it can be used to fulfill the tribunal's judicial function. Therefore the controversy upon it continues. Today such authority is likely to be assumed, even if not explicitly provided by the underlying arbitration agreement or applicable arbitral rules.

For example, the Iran-U.S. Claims Tribunal, which has defined the inherent powers of arbitral tribunals as 'those powers that are not explicitly granted to the tribunal but must be a necessary inherent power may be viewed as the "logical corollary of the judicial nature of such organs and of their duty to ensure a sound administration of justice." Meanwhile, according to a detailed study concept by Chester Brown, there are four ways that create inherent powers in international adjudication. First, inherent powers may be based on general principles. While often perceived as a subsidiary source of international law, it also has been used by international courts and tribunals in other contexts, such as: to develop the procedural law of international adjudication; as a source of substantive rights and obligations; to fill lacunae in the governing law, and to aid interpretation and the further development of international law. However, not all inherent powers may be justified in this manner since the general principle most likely does not cover all bases in cases where International Courts seek inherent powers (Gong, 2022).

Second, inherent powers can be found in the doctrine of implied powers. The exercise of implied powers might be regarded as an application of the principle of effectiveness in treaty interpretation. In order to differentiate between the inherent and implied powers is quite simple, the former concept relates to the nature of powers. Meanwhile, the latter explains the manner of their exposition in the particular instrument. For example, rules on competence, interim protection, preliminary objections, and intervention are inherent and expressly set out in the International Court of Justice (ICJ) statute. However, this theory is rarely used by international courts or tribunals to justify the exercise of power that is not clearly envisaged in their constitutive instrument, which can be seen from the limited case that using this theory (Salman, 2002).

Third, inherent powers are derived from the identity of courts as judicial bodies. The ICJ certainly included this basis in Nuclear Tests, stated that its inherent jurisdiction "derived from the mere existence of the court as a judicial organ established by the consent of states." Therefore, it is thought that it does not need any conferral. However, this view is criticized by legal scholars as a less satisfactory basis to maintain the nature of both courts and tribunals as source of inherent powers, because it is only a circular argument to maintain that both bodies gain inherent powers for 
the sole reason of their existences, since procedural power. Finally, it is suggested that the functional justification requires an identification of the functional purpose that needs to be fulfilled and can be taken into account as purposive treaty interpretation or a relevant customary rule (Pelcastre, 2016).

Fourth, inherent powers result from the necessity to ensure the fulfillment of the functions of international courts. This view is illustrated in the ICJ's statement in Nuclear Tests that inherent jurisdiction was granted to safeguard the court's judicial function, which reads as follows, it should be emphasized that the Court possesses an inherent jurisdiction enabling it to take such action as may be required, on the one hand, to ensure that the exercise of its jurisdiction over the merits, if and when established, shall not be frustrated, and on the other, to provide for the orderly settlement of all matters in dispute, to ensure the observance of the 'inherent limitations on the exercise of the judicial function' of the Court, and to 'maintain its judicial character'. Such inherent jurisdiction, on the basis of which the Court is fully empowered to make whatever findings may be necessary for the purposes just indicated, derives from the mere existence of the Court as a judicial organ established by the consent of states, and is conferred upon it in order that its basic judicial functions may be safeguarded (Jablonskaitè-Martinaitienè, I \& Točickienè, 2016).

Judicial function as a basis for inherent powers received support from legal doctrines which all can be concluded that the court is granted such necessary powers to fulfill its function. Additionally, the relevant judicial functions as the limit of inherent powers include the private section of settling disputes between parties and the public section that relates to the development of international law. Additionally, another view for the concept in the creation of inherent powers is suggested as a solution for different results that arises from applying the doctrine of implied powers, which is deemed inadequate between international courts and tribunals. Instead, the widespread application of inherent powers by international courts and tribunals, together with the engagement of entities to this practice, has given rise to an 'autonomous notion of inherent powers' of international judicial bodies that now constitutes a general principle of international law. In conclusion, according to Paola Gaeta, the general application will be an appropriate legal construct to enable tribunals in filling the lacunae in their constitutive instruments (Gertz et al., 2018).

Although inherent powers are not expressly stated in the constitutive instrument of the courts or tribunal, it does not mean that inherent powers can be assessed in an unlimited way. Legal scholars advise several suggestions in this regard. According to Chester Brown, several limitations in the exercise of inherent powers could flow from four sources which are explained below:

\section{Limitations of International Judicial Jurisdiction}

ICJ applied this limitation in the Northern Cameroons case in which it observed that 'the court is not compelled in every case to exercise that jurisdiction' whether or not it has jurisdiction over this matter and as a result discharge its duty to safeguard the judicial function. Several matters can be the reason behind this, such as: on the mootness of the issue, the absence of the third party that got affected in the dispute or for judicial propriety reasons.

2. Functions of the Particular Court

This limitation sets under the basis of the functions of each court which may vary one to each other because every court has a "unique" character which has to be taken into account when assessing the "unexpressed" inherent powers. As noted by Paola Gaeta, one court may exercise inherent powers that cannot be exercised in other courts, for instance, is International Criminal Court's power to act upon contempt of tribunal which is not necessary to inter-state courts.

3. Limitations in the Constitutive Instruments

There are three situations in which inherent powers will be displaced based on what is stated in the constitutive instrument of the court; where there is a clause contraire, the inherent power would be inconsistent with the constitutive instrument and obviously, when the courts or tribunals expressly removes their inherent powers.

4. The Relationship between The Particular Court and Parties 
The degree of deference displayed by each international court to the parties is particularly restrained the exercise of inherent powers. Chester Brown compares the common practices in ICJ and tribunals operate under PCA, ICSID and NAFTA to order the production of evidence. The former seems to be more reluctant in this matter.

Brown's concept is contended by Martins Paparinskis who suggested that instead of as limitations, the first three sources have functioned to the identification process of inherent powers' existence and scope. Meanwhile, the latest is not a specific rule that relates to the court's inherent powers, but more to the general aspect of international law making. For example, States can always create an international court without competence by explicitly removing this inherent power in the constitutive instrument. Moreover, Paola Gaeta also suggested taking into account the State's interest in the exercise of inherent powers, since the exercise of international courts is generally based on State's consent. Therefore, the inherent powers are not supposed to interference State's freedom and sovereignty. Further, inherent powers are also cannot be exercised when it restricts other international entities' freedom.

\subsection{The Inherent Power of Reconsideration in ICSID Arbitration}

ICSID Tribunals as international tribunals work under an international treaty, enabling them to settle disputes with States and apply international law. To support the existence of inherent powers under ICSID Arbitration, the Tribunal in the Libananco Holdings Co Limited v Turkey (Libananco) case noted that "nor does the Tribunal doubt for a moment that, like any other international tribunal, it must be regarded as endowed with inherent powers required to preserve the integrity of its process'. It can be seen that the existence of inherent power is deemed to be acceptable under ICSID Arbitration (Pratomo \& Kwik, 2020).

The broad existence of inherent powers is visible in various forms as noted by Martins Paparinskins in the matter as follows: to address abuse of process, regulate the conduct of counsel, grant enforceable orders (other than awards) regarding costs and permit the participation of amici curiae, order non-pecuniary remedies, regulate the conduct of counsel, regulate the conduct of proceedings, investigate bribery and grant enforceable orders regarding costs. In regard to the legal basis for the tribunal to exercise its inherent powers, it is undoubted that the ICSID Convention provides it under Article 44 which reads as follow any arbitration proceeding shall be conducted in accordance with the provisions of this section and, except as the parties otherwise agree, in accordance with the Arbitration Rules in effect on the date on which the parties consented to arbitration. If any procedure question arises that is not covered by this section or the Arbitration Rules or any rules agreed by the parties, the Tribunal shall decide the question (Alpkokin \& Capar, 2019).

This article explicitly enables the tribunal to decide the question submitted to them that is not covered by the Convention, the ICSID Arbitration Rules, or any rule agreed by the parties. Furthermore, Article 19 of ICSID Arbitration Rules also grants the tribunal authority to make the orders required for the conduct of the proceeding. Christoph H. Schreuer provides a doctrine which supports tribunal's inherent power, 'an ICSID tribunal's power to close gaps in the rules of procedure is declaratory of the inherent power of any tribunal to resolve procedural questions in the event of lacunae'. Parties in various cases of ICSID Arbitration often use this doctrine to support their arguments in exercising tribunal's inherent powers (Puig, 2013).

The Tribunal in Abaclat et al. v. Argentina limited this power only to fill gaps left by the ICSID Convention and the Arbitration Rules. This tribunal carefully stressed that the tribunal's power to fill gaps, inferred from the ICSID procedural framework, was limited to the specific proceedings only, means that the tribunal who exercising its power under Article 44 of the ICSID Convention does not aim to complete or improve the ICSID framework that will generally applied, but rather to respond to 'specific problems arising in the specific proceedings at hand'. The ICSID Convention contains inherent power which is "expressed" in several articles. Article 41 provides competence, Articles 43 and 45 provide for certain evidentiary powers, Article 46 provides for powers regarding counterclaims, Article 47 provides for powers to indicate (binding) provisional measures, Articles 50 and 51 provide powers of respectively interpretation and revision. 
In addition, number of functions relevant to the exercise of inherent powers are identified from ICSID cases which include the protection of the integrity of process, dealing with vexatious claims, promoting fair and efficient dispute resolution, securing interests of justice and interests of parties. These facts lead to the limitation of ICSID Tribunal's inherent powers, which may be integrated into the identification of inherent powers existence or reflect the proposition that States can derogate intersection from rules of jus dispositivum. Generally, ICSID Tribunals have confirmed that although the Tribunal does have certain inherent powers concerning arbitral procedure, it has no authority to exercise such power in opposition to a clear directive in the Arbitration Rules.

Therefore, the authorization for the tribunals to exercise inherent powers is granted as long it is still within the high standard of the framework of rules available for ICSID Arbitration. This open to the Tribunal's interpretation regarding whether the inherent powers demanded are necessary in the arbitration proceedings and still in line with the directives and automatically leads to different results of judgment concerning inherent matters in ICSID cases that happens in three cases assessed in this study. The further explanation relates to this matter will be discussed in the next section. The reconsideration power can be derived from several articles and circumstances. However, in the situation where all ICSID frameworks (ICSID Convention, Arbitration Rules or an agreement between parties) are in silence regarding procedural matters, then it is determined as a "gap" that needs to be fulfilled under Article 44 of the ICSID Convention. Article 44 grants the tribunal residual power to "fill the gap" that must be exercised within the scope outlined in this article. As the matter of practice, the reconsideration power can be enforced based on this article.

The next article is Rule 19 of Arbitration Rules, which can complement the previous article as a legal basis when a tribunal intends to enforce additional powers to fulfill its duty. It rules that a tribunal should make the orders required to answer the questions submitted to them. If there is an absence of conduct and a specific conduct is necessary to fulfill tribunal's duty, they might take additional conducts. In addition to articles that have mentioned earlier, Rule 38 (2) of Arbitration Rules can be used as a source to create power of reconsideration for the tribunals, especially in a situation where new evidence is discovered before the tribunals rendering judgment. Further, this article sets a standard that this new evidence must have decisive factors or have an urgent sense to be clarified by either party.

In this regard, it is also worth mentioning the Tanesco Tribunal's suggestion in using Article 51 of the ICSID Convention as a guide for a tribunal in exercising power to reconsider their decisions, especially after a fact has been discovered of such a nature as to decisively affect the decision of the tribunal, besides this article also can be the guidance for a tribunal in exercising a power to re-open a decision. However, it is not bound by the limitations on re-opening that apply to awards. Article 51 gives specific circumstances when a party can seek revision after discovering new evidence provided that these new facts are decisive to the outcome of the case. Although this article is for final award, the Tanesco Tribunal suggested it be applied as a framework for the tribunal in judging the reconsideration motion. This aims to prevent unlimited uncertainty because the tribunal is asserted with too broad power to reconsider.

In the history of international dispute settlement, several methods for reconsidering or re-opening a case have emerged. The power of reconsideration is acknowledged as a part of tribunals' inherent powers in some judgments, although it meets obstacles to be established in several other judgments as can be seen from three cases presented in this study. The question whether reconsideration power is included in the inherent powers class to be enforceable by the tribunal cannot be answered in a simple way, especially because the reconsideration motion often being opposed with the finality issue of the decision prior to award in question as seen in Conoco Phillips, Churchill and Perenco. Moreover, as previously explained, the finality character of the interim decision under ICSID Arbitration is still in the debate between legal scholars and each tribunal facing the same matter had released different interpretation.

From two of three cases presented in this study, the Conoco Phillips and Perenco rejected the establishment of power to reconsider which demanded by each Respondent in both cases using Article 44 as a part of their reasoning. The majority of Conoco Phillips and Perenco tribunals prioritized the finality character of tribunals' decision in rejecting this motion. They viewed the interim decisions to be incorporated to the final award; therefore, it cannot be revisited by the 
tribunal or the parties in any later stage of the proceedings. This finding means that the interim decision is deemed to have res judicata effect same as the final award, there is no other way to reopen, revise or amend it other than with post-judgment remedies.

In the perspective of the majority of Conoco Phillips Tribunal, Article 44 was designed to fill procedural gaps and did not confer a 'broad unexpressed power' of reconsideration. Therefore, this tribunal acknowledged that such power to reconsider is more substantive and can only be exercised once the final award has been rendered. In this case, the decision to reject the reconsideration motion is confusing since the motion was based on a clear error of law discovered after the decision was rendered. The new evidence found in Wikileaks cables which show how respondent was negotiating fair-market value and reflects the entitlement of benefits for Conoco Phillips would have changed the direction of this case, as it proved that the Respondent is not showing bad faith as it was claimed by the claimant provided in the decision held by the Tribunal in question. However, the Tribunal rejected the view that the grounds and new evidence on which the Respondent based its request are decisive to creating its reconsideration power.

In almost similar fashion, even though the Perenco tribunal held that Article 44 does not give any general power to re-open or reverse, nor does the Tribunal view the view of such a general power to be a lacuna that needs to be filled for decision prior the final award rendered by the tribunal, but the Perenco tribunal appears to avoid expressing a view on whether there would be a specific power to reopen in the light of particular facts. This tribunal denied exercising reconsideration power with the discovery of error of facts, since it is insufficient to grant them such power. When a decisive error of fact is acknowledged once the Tribunal has already rendered the decision, it is supposed to be a sufficient basis for vesting the Tribunal power of reconsideration. Res judicata is endogenous to the concept of appeal which is used to find fault in the judgment (in whichever ground - fact or legal).

However, it should not be applied in this condition since the error of fact affects the completeness of the final award that will be rendered later. It is unarguably correct that any fault found in the judgment can be revised by submitting the application to the Secretary-General under Article 52 of the ICSID Convention, however when the Convention provides legitimacy for the tribunal to "fill the gap" in the arbitration proceeding that is still ongoing with taking any necessary conduct to answer any submitted questions, as long it is not against the directive, then the tribunal should exercise its power. However, to avoid any misinterpretation by the tribunal in enforcing this approach, it is indeed necessary to provide specific rules regarding this matter. However, the Churchill Tribunal acknowledged Article 44 of the ICSID Convention as a source of its discretionary power to re-open, and, if appropriate, amend previous procedural orders in matters of procedures not covered by the ICSID Convention.

Using this study as a legal ground reaffirmed its previous decision that consideration should be the prevailing test when it comes to case management and that such efficiency is primarily dependent on whether the resolution of the forgery issue is dispositive of the case. Article 44 of the ICSID Convention indicates that any power needed to answer any question submitted to the tribunal in so far, the arbitration proceeding is still going must be exercised. The Churchill Tribunal saw this 'general power' - a gap-filling power- as procedural within the context of pending proceedings. Therefore, when the tribunal was provided by the Respondent detailed submissions showing that all the claims would have to be dismissed if the relevant documents were forged, then it was convinced that amending the Procedural Order No. 12 to be necessary.

George Abi-Saab specifically answers a similar issue regarding the tribunal's general power to reconsider his well-known dissenting opinion for Conoco Phillips upon the Respondent's reconsideration motion. George Abi-Saab observed that the ICSID procedural system has "peculiarity" which aims to have all questions submitted to the tribunal in one complete award which might include the total balance of equities. This makes "finality" appears once all questions are answered. Further, he stressed that ICSID has lex specialis different with other International Court (ICJ, ICC and others), that considers interlocutory decisions final and open to post-judgment remedies. Under his view, a general power to reconsider interlocutory decisions is granted to the ICSID tribunals that can be made within certain limitations or under certain conditions in a case still pending before it. 
Moreover, in his dissenting opinion, George Abi-Saab mentioned Article 44 of the ICSID Convention as a partial codification and specific application of the inherent jurisdiction or powers of any judicial or adjudication organ. This inherent jurisdiction or power should be used to ensure and safeguard the adjudicative organ's efficiency, credibility, and integrity with seeking truth and justice as the main task. In reaching these purposes, according to George Abi-Saab, it is where the reconsideration power lies. Further, as already discussed in the previous section, citing Chester Brown's theory, the inherent power of the international court or tribunal can be established based on the necessity to fulfil its judicial function by enforcing inherent powers. This doctrine also can support the establishment of reconsideration power under Article 44 of the ICSID Convention.

Lastly, it can be concluded that when one strictly makes finality and legal certainty as the starting point of their judgment over reconsideration request in dispute settlement will most likely deny the existence of reconsideration power. On the other hand, when the principle of correctness becomes the main concern of the tribunal, then reconsideration might be granted. Above from all, if a tribunal denies using such power when it is justified for them to do so by some legal reasoning in the situation where they have unanswered questions related to the case, then the "final award" which later they render most likely are incomplete, and as a consequence, that award is not award under Article 53 (1) of the ICSID Convention and does not give any res judicata effect to the parties.

\subsection{The Limitations of Tribunal's Inherent Power of Reconsideration}

After it is established that reconsideration power has legitimacy under ICSID, then it is also important to bear in mind that in supporting reconsideration power, the exercise of such power is acknowledged to be within the limited circumstances. As explained in the previous section by citing the Tribunal in Aguas case, tribunals' inherent powers are not absolute and find its limitations in the available rules such as ICSID Convention, Arbitration Rules, or an agreement between the parties. This aims at promoting legal certainty. Significantly, according to McDougall and Markbaoui, a reconsideration motion might hinder less efficiency of ICSID arbitration by tempting the losing parties in the partial decisions to bring time-consuming requests for reconsideration regardless of whether they are well-founded. Several potential limitations can be identified based on several issues arising in three cases analyzed in this thesis and other sources such as literature and doctrines.

The first issue has appeared in the conclusion of the Conoco Phillips majority that rejected the reconsideration of its decision on jurisdiction, holding that, "as a matter of principle and practice", ICSID tribunal decisions are res judicata and intended to be final. As remained earlier in paper of this study, the finality of pre-award in ICSID Arbitration remains uncertain, it is always left to the tribunal's interpretation. When it came to the case where reconsideration power became the concern, the case's outcome will vary based on which principle the tribunal is more favoring. In both Conoco Phillips and Perenco tribunals, the principle of finality and the efficiency of the proceedings are more favored. The different view is found in Georges Abi-Saab's dissenting opinion as the principle of correctness is clearly steered his opinion.

The second issue is even though not expressly stated in the judgment of Churchill Tribunal, reconsideration power as tribunal's inherent power is not so broad and unlimited, but it is wellexplained in there that the reconsideration power needs to be exercised within the standard contained in Article 44. Therefore, a tribunal should only exercise the reconsideration power when the circumstances of the case already fulfill this standard. Moreover, as found in the case which the tribunal held that reconsideration power only enforceable in the individual case depending on the circumstances, which means that the issue for reconsideration power is preferred to be considered case-by-case and not to be generally accepted. The tribunal needs to decide depending on the circumstances of each case carefully.

Additionally, another limitation to enforce reconsideration power can be cited from waste management which shows the view that not only awards are subject to remedies such as interpretation, revision, or annulment, when the tribunal is still exercising its functions, given that it had the power, while still exercising its functions and prior to the closure of the proceedings, to give any necessary supplementary decision, and to correct any error in the translation of a decision. In the same vein, the supporting doctrine in this matter is also provided by Christoph H. Schreuer: "Art. 51 
is designed specifically for situations in which the tribunal has terminated its activity. A tribunal that is still in session can always revise its preliminary decisions informally."

Both statements above indicate the existence of reconsideration power with limitation in the specific period for tribunals only when they are still in session, which means before rendering the final award and not yet in functus officio. Eventually, all these limitations should help the Tribunals reach the balance between protecting the efficiency of the proceedings and assuring a minimum of correctness for the award- between finality and correctness. However, to support uniformity between ICSID tribunals when handling the same issue, it is necessary to provide additional rules related to the inherent powers of reconsideration. This rule may contain standards that need to be fulfilled, such as specific circumstances that can be the ground for a tribunal to possess such power and further guidance regarding the non-extended finality character for decision prior to the award. Limiting the scope of the reconsideration or revision of interlocutory decisions through exigent and predictable factors, means that the Tribunal has to protect the efficiency and the predictability of arbitral proceedings.

\section{Conclusion}

To conclude, the ICSID tribunal's inherent reconsideration power can be exercised to "fill the gap" in arbitration proceedings. First, it can be enforced under Article 44 of ICSID Convention. This study grants a power to decide the question submitted to the tribunal, which is not covered by the ICSID Convention, Arbitration Rules or an agreement between parties. Second, in completing this article, the wording of Rules 19 of Arbitration Rules literally gives an almost similar order to the tribunals in the case of absence in the conduct of proceedings. This rule also opens a way for the tribunal to re-open or amend its prior decision when it is necessary. Third, under Rule 38 (2) Arbitration Rules, the reconsideration power can be exercised by the tribunals when there is the discovery of new facts that decisively affect the outcome of the case. However, it seems that applying these articles to create reconsideration power is not a simple job for the tribunals. The tribunals often rejected the reconsideration motion as they ruled their decision prior to the final award as having a res judicata effect and cannot be re-open or amend in any later stage except with post-judgement remedies. Moreover, the discovery of error of fact should be considered sufficient ground for the tribunal to re-open or even amend its earlier decision when such a decision is decisive to the final award. If a "final award" contains unanswered questions or errors of fact, it does not fulfil the term 'award' as provided in Article 53 (1) of the ICSID Convention. In this regard, I suggest that a specific rule in reconsideration power is provided for future guidance for the tribunal.

\section{References}

Alpkokin, P., \& Capar, M. S. (2019). Dispute boards in Turkey for infrastructure projects. Utilities Policy, 60, 100958. https://doi.org/10.1016/j.jup.2019.100958

Arthur, J. P. H. (2015). The legal value of prior steps to arbitration in international law of foreign investment: Two (different?) approaches, one outcome. Anuario Mexicano de Derecho Internacional, 15(1), 449-491. https://doi.org/10.1016/j.amdi.2015.06.004

Bhagwat, V., Brogaard, J., \& Julio, B. (2021). A BIT goes a long way: Bilateral investment treaties and cross-border mergers. Journal of Financial Economics, 140(2), 514-538. https://doi.org/10.1016/j.jfineco.2020.12.005

Chisik, R. (2012). Trade disputes, quality choice, and economic integration. Journal of International Economics, 88(1), 47-61. https://doi.org/10.1016/j.jinteco.2012.01.010

Chou, J.-S., Hsu, S.-C., Lin, C.-W., \& Chang, Y.-C. (2016). Classifying influential information to discover rule sets for project disputes and possible resolutions. International Journal of Project Management, 34(8), 1706-1716. https://doi.org/10.1016/j.ijproman.2016.10.001

Deffains, B., Gabuthy, Y., \& Lambert, E.-A. (2010). Labour disputes, investment decisions and the judiciary. Labour Economics, 17(2), 424-433. https://doi.org/10.1016/j.1abeco.2009.05.002 
Gershoni, N. (2021). Individual vs. group decision-making: Evidence from a natural experiment in arbitration proceedings. Journal of Public Economics, 201, 104479. https://doi.org/10.1016/j.jpubeco.2021.104479

Gertz, G., Jandhyala, S., \& Poulsen, L. N. S. (2018). Legalization, diplomacy, and development: Do investment treaties de-politicize investment disputes? World Development, 107, 239-252. https://doi.org/10.1016/j.worlddev.2018.02.023

Gong, X. (2022). Energy security through a financial lens: Rethinking geopolitics, strategic investment, and governance in China's global energy expansion. Energy Research \& Social Science, 83, 102341. https://doi.org/10.1016/j.erss.2021.102341

Horn, H., \& Tangerås, T. (2021). Economics of international investment agreements. Journal of International Economics, 131, 103433. https://doi.org/10.1016/j.jinteco.2021.103433

Inga Jablonskaitè-Martinaitienè, \& Točickienè, N. (2016). Procedure before the European Union Civil Service Tribunal: Specific aspects. International Comparative Jurisprudence, 2(1), 45 54. https://doi.org/10.1016/j.icj.2016.05.002

Junxia, L. (2019). Investments in the energy sector of Central Asia: Corruption risk and policy implications. Energy Policy, 133, 110912. https://doi.org/10.1016/j.enpol.2019.110912

Kohler, W., \& Stähler, F. (2019). The economics of investor protection: ISDS versus national treatment. Journal of International Economics, 121, 103254. https://doi.org/10.1016/j.jinteco.2019.103254

Nyarko, J. (2019). We'll See You in . . . Court! The lack of arbitration clauses in international commercial contracts. International Review of Law and Economics, 58, 6-24. https://doi.org/10.1016/j.irle.2018.12.004

Oseni, U. A., Adewale, A., \& Mohd Zain, N. R. B. (2016). Customers' perceptions on the dispute resolution clauses in Islamic finance contracts in Malaysia. Review of Financial Economics, 31, 89-98. https://doi.org/10.1016/j.rfe.2016.05.004

Pelcastre, I. F. (2016). A tailor-made (Legal) suit? The actual scope, power, and functioning of nafta Chapter 11's rules and institutions for the settlement of cross-border disputes. Norteamérica, 11(1), 9-42. https://doi.org/10.20999/nam.2016.a001

Pratomo, E., \& Kwik, J. (2020). Good agreements make good neighbours: Settlements on maritime boundary disputes in South East Asia. Marine Policy, 117, 103943. https://doi.org/10.1016/j.marpol.2020.103943

Puig, S. (2013). Investor-state tribunals and constitutional courts: The Mexican sweeteners saga. Mexican Law Review, 5(2), 199-243. https://doi.org/10.1016/S1870-0578(16)30024-5

Rao, W. (2021). Are arbitrators biased in ICSID arbitration? A dynamic perspective. International Review of Law and Economics, 66, 105980. https://doi.org/10.1016/j.irle.2021.105980

Salman, S. M. A. (2002). Inter-states water disputes in India: an analysis of the settlement process. Water Policy, 4(3), 223-237. https://doi.org/10.1016/S1366-7017(02)00030-2

Thiel, F. (2018). Regulatory or expropriatory? On the implications of the Transatlantic Trade and Investment Partnership for the German land policy. Land Use Policy, 77, 778-789. https://doi.org/10.1016/j.landusepol.2017.01.015

Thow, A. M., Snowdon, W., Labonté, R., Gleeson, D., Stuckler, D., Hattersley, L., Schram, A., Kay, A., \& Friel, S. (2015). Will the next generation of preferential trade and investment agreements undermine prevention of noncommunicable diseases? A prospective policy analysis of the Trans Pacific Partnership Agreement. Health Policy, 119(1), 88-96. https://doi.org/10.1016/j.healthpol.2014.08.002 